Debate

\title{
Saúde do Trabalhador no SUS: desafios para uma política pública
}

Worker's Health within the Brazilian Unified Health System: challenges for a public policy (continuação/continuance)

Artigo em debate:

COSTA, Danilo; LACAZ, Francisco Antonio de Castro; JACKSON FILHO, José Marçal; VILELA, Rodolfo Andrade Gouveia. Saúde do Trabalhador no SUS: desafios para uma política pública. Revista Brasileira de Saúde Ocupacional, São Paulo, v. 38, n. 127, p. 11-21, 2013.

Disponível em:

http://www.scielo.br/scielo.php?script=sci_arttext\&pid=S0303-76572013000100003\&lng=pt\&nrm=iso.

http://dx.doi.org/10.1590/S0303-76572013000100003.

Os textos a seguir dão seguimento ao debate iniciado em torno do artigo acima referenciado, publicado no primeiro número do dossiê temático Atenção integral em Saúde do Trabalhador: desafios e perspectivas de uma política pública. No primeiro número, foram dois os debatedores e, neste, são mais quatro convidados, aos quais a RBSO agradece pelas expressivas contribuições.

Além dos manuscritos dos debatedores, este segundo número completa o dossiê com mais quatro artigos, dois ensaios, uma revisão, dois relatos de experiência e uma resenha, trazendo suas contribuições para a discussão deste tema fundamental para o campo da Saúde do Trabalhador. 